\title{
Investigating the Effect of Probiotics as Natural Preservatives on the Microbial and Physicochemical Properties of Yogurt-Marinated Chicken Fillets
}

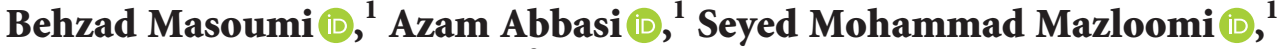 \\ and Samaneh Shaghaghian ${ }^{2}{ }^{2}$ \\ ${ }^{1}$ Nutrition Research Center, Department of Food Hygiene and Quality Control, School of Nutrition and Food Sciences, \\ Shiraz University of Medical Sciences, Shiraz, Iran \\ ${ }^{2}$ Technical Manager, Food Laboratory of Pars Pajhouhan Sanjesh Pouya, Shiraz, Iran
}

Correspondence should be addressed to Azam Abbasi; azamabbasi1387@gmail.com

Received 15 August 2021; Accepted 29 December 2021; Published 7 January 2022

Academic Editor: Shudong He

Copyright ( 2022 Behzad Masoumi et al. This is an open access article distributed under the Creative Commons Attribution License, which permits unrestricted use, distribution, and reproduction in any medium, provided the original work is properly cited.

\begin{abstract}
Microbial flora of probiotic yogurt can have nutraceutical properties and improve beneficial health effects of food products. In this study, microbial and physicochemical properties of raw chicken fillets dipped in regular yogurt and probiotic yogurt containing Lactobacillus casei, preserved at $4^{\circ} \mathrm{C}$ for 9 days, were studied. In this regard, microbial analysis (Staphylococcus aureus, fecal coliform, yeasts, and molds) and physicochemical analysis ( $\mathrm{pH}$, water holding capacity, cooking loss percentage, Thiobarbituric acid reactive substances, and texture profile analysis) were performed during the storage time. In comparison with control samples, the amount of Staphylococcus aureus, fecal coliforms, yeast and mold counts, $\mathrm{pH}$ index, malondialdehyde value, and cooking loss percentage reduced significantly $(P<0.05)$ in the chicken fillets treated with regular and probiotic yogurt, while the water holding capacity increased in six days. It was concluded that probiotic and regular yogurts reduced microbial growth and improved the physicochemical quality of chicken fillets during storage and cooking time.
\end{abstract}

\section{Introduction}

Nowadays, the consumption of chicken meat has increased remarkably due to its low cost compared to red meat and high nutritional values and health effects [1]. The fresh poultry is susceptible to microbial growth and lipid oxidation due to the high protein, moisture, and fat content. Preventing microbial growth and retarding lipid oxidation can be reached through a series of methods to maintain the quality and safety of chicken meat [2]. Some of these methods are artificial drying $[3,4]$, vacuum packaging $[5,6]$, ionizing radiations [7], high pressure processing [8], applying chemicals [9], and using antimicrobial metabolites of fermentative microorganisms $[10,11]$. In recent years, using probiotics as microbial preservatives has drawn a lot of attention due to the consumers' concern about artificial additives.
Probiotics play an important role in human health. Besides, they can inhibit pathogen growth and prolong the shelf-life of food [12]. In this regard, mostly lactic acid bacteria (LAB) and bifidobacteria are used in probiotic foods [13]. Some of the important features of probiotic bacteria are resistance to gastric acidity and bile salt, adherence to mucus, and/or intestinal epithelial cells and cell lines, as well as antimicrobial and antagonistic activity against potentially pathogenic microbes by producing some secondary metabolites [14]. Use of probiotics to extend the shelf-life of foods as a kind of biological preserving method is performed in two approaches: (i) immersing or inoculating food matrix with a protective culture containing probiotic microorganisms with competitive effect against pathogenic or spoilage microbial factors and (ii) using purified secondary metabolites produced by probiotic microorganisms such as 
bacteriocins [15]. Bacteriocins bind to food components such as lipid or protein particles or food additives [16], whereby they show their antimicrobial properties. Protective cultures have some advantages, such as producing secondary metabolites with antimicrobial effects (organic acids, carbon dioxide, ethanol, hydrogen peroxide, and diacetyl), as well as restricting the growth of undesired organisms by competing over nutrient supplies. They also contribute to the formation of flavor components, texture improvement, and increasing the nutritional values $[12,13,17,18]$. Maragkoudakis et al. (2009) studied the application of live lactic acid bacteria on the microbial quality of raw chicken meat and evaluated 635 LAB as protective cultures in food products. Through stepwise screening methods, two strains (Enterococcus faecium PCD71 and Lactobacillus fermentum ACADC179) were selected as the protective culture. They retarded spoilage by reducing the growth rate of Listeria monocytogenes and Salmonella enteritidis with no reduction in nutritional values [19]. Göğusş et al. (2004) examined the effect of nisin, oil-beewax coating, and yogurt on the quality of refrigerated chicken meat. They found that dipping chicken carcasses in yogurt for $5 \mathrm{~h}$ followed by $20 \mathrm{~min}$ immersion in nisin as well as coating with oil-beewax reduced the mesophilic aerobic bacteria by $2.11 \log \mathrm{CFU} / \mathrm{g}$, while dipping in yogurt for $5 \mathrm{~h}$ and then $20 \mathrm{~min}$ in nisin reduced Salmonella by $1.97 \log \mathrm{CFU} / \mathrm{g}$, respectively [20].

Yogurt is very popular in Iran to marinate chicken meat due to enhancing the flavor and texture of chicken meat. In the Middle East, yogurt-marinated chicken fillets can be barbequed or applied as a food ingredient. The aim of this study was to investigate the effect of using regular and probiotic yogurt on microbial properties and physicochemical characteristics of chicken fillets stored in the fridge $\left(4^{\circ} \mathrm{C}\right)$ for 9 days.

\section{Materials and Methods}

Fresh skinless chicken breast fillets were purchased from a local market in Shiraz (Fars, Iran) and immediately transferred to the laboratory in insulated iceboxes. They were sliced into approximately equal cubes using a sterilized knife and kept in plastic bags at $4^{\circ} \mathrm{C}$ before marinating. Lactobacillus casei and commercial yogurt culture YC-X11 were purchased from Chr. Hansen, Hørsholm, Denmark, and Yeast extract Glucose Chloramphenicol agar (YGC) was purchased from Merck Co., Germany. Fecal coliforms (ECC) and Staphylococcus aureus chromogenic medium were prepared from CHROMagar, Paris, France. BHT (butylated hydroxy toluene), TBA (thiobarbituric acid), TCA (trichloro acetic acid), and MDA (malondialdehyde) were purchased from Sigma-Aldrich Co., USA.

2.1. Preparation of Starter Cultures. Adequate amounts of low-fat homogenized and sterilized milk $(3.62 \%$ protein, $3.61 \%$ lactose, $1.6 \%$ fat, and $9.70 \%$ total solid) were heated to $95^{\circ} \mathrm{C}$ for $10 \mathrm{~min}$ and then cooled down to $40^{\circ} \mathrm{C}$. For regular yogurt starter preparation, $0.1 \%(\mathrm{w} / \mathrm{v})$ of commercial yogurt culture (YC-X11) consisting of Streptococcus thermophilus and Lactobacillus delbrueckii spp. Bulgaricus was added to the milk. To prepare probiotic yogurt starter (fermented milk), $0.1 \%(\mathrm{w} / \mathrm{v})$ of Lactobacillus casei (L. CaseI $431^{\circledR}$ ) was added to the desired amount of milk. Thereafter, regular and probiotic yogurt starters were incubated at $40^{\circ} \mathrm{C}$ and $37^{\circ} \mathrm{C}$, respectively, until the $\mathrm{pH}$ reached 4.6. The yogurt samples were refrigerated at $4^{\circ} \mathrm{C}$ and used as starter cultures.

2.2. Preparation of Yogurts. Regular yogurt (RY) was prepared by mixing $3 \mathrm{ml}$ of regular yogurt starter with $1000 \mathrm{ml}$ of milk. The mixture was incubated at $40^{\circ} \mathrm{C}$ for $6 \mathrm{~h}$. The $\mathrm{pH}$ of the mixture was measured every $60 \mathrm{~min}$ using a $\mathrm{pH}$ meter (Metrohm 827, Switzerland) until the $\mathrm{pH}$ of yogurt reached 4.6. For the preparation of probiotic yogurt (PY), $2 \mathrm{ml}$ of probiotic yogurt starter (to give probiotic properties and aroma to yogurt) and $1 \mathrm{ml}$ of yogurt starter (to coagulate and fermentation of milk to obtain firm gel) were blended and then added to $1000 \mathrm{ml}$ of milk. This mixture was then incubated at $37^{\circ} \mathrm{C}$ for $8 \mathrm{~h}$ until the $\mathrm{pH}=4.6$ was obtained. To determine the probiotic enumerations and viability, microbial analysis was done by preparing appropriate dilutions of probiotic yogurt plated on acidified MRS agar. Results show that the number of Lactobacillus casei in probiotic yogurt samples after $6 \mathrm{~h}$ of incubation reached $9.4 \times 10^{8} \mathrm{CFU} / \mathrm{ml}$ and after 9 days of storage at $4^{\circ} \mathrm{C}$ was $5.2 \times 10^{7}$, which showed the proper viability of probiotic bacteria.

2.3. Sample Preparation. The sliced untreated chicken meats were stored at the fridge as control samples. The marinating procedure was performed at room temperature by dipping the fillets into 2 lit of regular yogurt or probiotic yogurt for $1 \mathrm{~min}, 2$ times repeatedly after $2 \mathrm{~min}$. The amount of yogurt covered marinated fillets was $10 \% \pm 0.2(\mathrm{w} / \mathrm{w})$ after the excess yogurt was drained off. All samples were packed in sterile polystyrene plastic bags and kept at $4^{\circ} \mathrm{C}$. Sampling was performed on days $0,2,6$, and 8 of storage for chemical analysis, 0,3 , and 6 of storage for texture analysis, and $0,3,5$, 7 , and 9 of storage for microbial analysis.

2.4. $\mathrm{pH}$ Measurement. $0.5 \mathrm{~g}$ of chicken fillet sample was completely homogenized in $10 \mathrm{ml}$ of distilled water and stirred for $10 \mathrm{~s}$. The $\mathrm{pH}$ was measured using a digital $\mathrm{pH}$ meter (PH-Meter 827, Metrohm, Switzerland).

2.5. Measuring Cooking Loss. To estimate the cooking loss, chicken fillet samples were weighed and cooked in oven at $75^{\circ} \mathrm{C}[21,22]$. After cooling down, the cooked samples were reweighed at the room temperature. The percentage of weight loss relative to the initial weight was reported as cooking loss [23].

2.6. Expelled Water Measurement. Expelled water (EXW) measurement is based on the free water expelled by samples of chicken meat slices. Chicken meat slices weighing $0.5 \mathrm{~g}$ were placed between two Whatman paper filters (No. 40) 
and two glass plates, with $10 \mathrm{~kg}$ load on top of the plate for 5 minutes. The percentage of weight loss of chicken meat slices after the pressure relative to the initial sample weight represents the fee water expelled from the samples, which have the reverse relation with the water holding capacity (WHC) of the samples [21, 23].

2.7. Lipid Oxidation Determination. The lipid oxidation was evaluated colorimetrically by TBARS test (thiobarbituric acid reactive substances) described by Pokorny (1989). The degree of oxidation was determined in $0,2,6$, and 8 days of storage. Briefly, $1 \mathrm{~g}$ of minced chicken meat was mixed into $10 \mathrm{ml}$ of deionized water and filtered through Whatman paper (No. 40). $2 \mathrm{ml}$ of the filtered sample was mixed with $4 \mathrm{ml}$ of thiobarbituric reactive reagent (prepared by dissolving $0.187 \mathrm{~g}$ TBA and $7.5 \mathrm{~g}$ TCA in $1.5 \mathrm{ml}$ of $2 \%$ BHT ethanolic solution and reached to $100 \mathrm{ml}$ by $\mathrm{HCl} 0.25 \mathrm{M}$ ). For color development, the mixture was incubated at $90^{\circ} \mathrm{C}$ for $15 \mathrm{~min}$, and after cooling down, the absorbance was measured at $532 \mathrm{~nm}$ against ethanol as the blank. To determine the concentration of malondialdehyde in samples, the absorbance of standard solutions of malondialdehyde was measured for the calibration curve. TBARS values was reported in milligrams of malondialdehyde per kilograms of chicken breast meat $[24,25]$.

2.8. Texture Profile Analysis. The hardness, cohesiveness, springiness, gumminess, and chewiness of chicken samples were measured using the texture analyzer (CT3 Texture Analyzer; Brookfield Engineering Laboratories) according to the method of De Huidobro with some modifications [26]. To analyze the texture of chicken samples, the stainless-steel cylindrical probe (TA41 model: $7 \mathrm{~g}$ weight and $6 \mathrm{~mm}$ diameter, $35 \mathrm{~mm}$ height) was used. Chicken breast meats were cut into slices $20 \mathrm{~mm}$ in diameter and $25 \mathrm{~mm}$ in thickness and were compressed twice with the probe to $50 \%$ of their thickness at $2 \mathrm{~mm} / \mathrm{s}$. Data collection and computation (hardness, cohesiveness, springiness, gumminess, and chewiness) were performed using specialized software (TexturePro CT, Brookfield, USA).

2.9. Microbial Analysis. A total of $25 \mathrm{~g}$ of the chicken meat sample was homogenized in $225 \mathrm{ml}$ of distilled water using a stomacher for $2 \mathrm{~min}$. The homogenized samples were serially diluted, and the yeast and mold counts were determined according to the method by Alexopoulos (2013) on YGC agar media at room temperature for 3 to 5 days. For the counting of Staphylococcus aureus and total fecal coliforms, CHROMagar S. aureus and CHROMagar ECC culture media were applied, using the pour plate method, incubated at $37^{\circ} \mathrm{C}$ for $48 \mathrm{hr}$ and $24 \mathrm{hr}$, respectively. The pink-to-purple color colonies indicated Staphylococcus aureus growth, while red color colonies represented fecal coliforms. The results of microbial analyses were reported as logarithms of colony-forming units (CFU) per Gram of sample $\left(\log _{10} \mathrm{CFU} / \mathrm{g}\right)$.
2.10. Statistical Analysis. All experiments were performed at least three times and analyzed using SPSS version 21.0. Oneway ANOVA, repeated measure ANOVA, and Duncan's post hoc test were used to compare the means at a confidence level of 0.05 .

\section{Results and Discussion}

3.1. $\mathrm{pH}$ Value. Changes in $\mathrm{pH}$ values of the samples stored at $4^{\circ} \mathrm{C}$ for 8 days are reported in Table 1 . The initial $\mathrm{pH}$ of chicken fillets was 6.15 , while it dropped significantly to 4.7 after 8 days of storage in both treated groups. The $\mathrm{pH}$ increase to 7.92 in the control group may be due to the accumulation of alkaline compounds, such as ammonia and total volatile basic nitrogen (TVB-N), produced through microbial spoilage [27]. The results of the previous works were in agreement with the present study. Grajales et al. (2012) investigated the effect of lactic acid bacteria on the chemical properties and the taste of pork meat. They found that the $\mathrm{pH}$ index of treated samples increased after 7 days of storage. They concluded that the proteolysis of protein and its conversion to organic acids leads to the $\mathrm{pH}$ increase [28]. Thus, in the present study, lactic acid bacteria in both regular and probiotic yogurts can act as a $\mathrm{pH}$ lowering agent. Fraqueza et al. (2008) studied the spoilage of Turkey meat and concluded that the activity of lactic acid bacteria overtakes the proteolytic bacteria and causes the medium to become acidic [29]. The results of another study by Gögüş et al. (2004) also indicated a decrease in the $\mathrm{pH}$ in chicken meats coated with yogurt [20].

3.2. Cooking Loss and EXW. Cooking loss is a major factor affecting the appearance and acceptance of chicken meat. The amount of cooking loss in the control group increased constantly during the storage time, though this increase was not statistically significant (Table 1). On the other hand, the amount of cooking loss of treated chicken fillets decreased significantly (\%48 and \%44 for RY-treated fillets and PYtreated fillets, respectively) during the storage time. Cooking loss refers to the weight loss of the meat during the cooking process, when its central temperature reaches $75^{\circ} \mathrm{C}$. According to the free water expelled (EXW) measurement, the control group showed the greatest amount of WHC (more water expelled) on the second day; however, it increased during the storage period. In RY-treated samples, the ascending trend of EXW was statistically significant and the lowest amount of WHC was reached on the sixth day. Probiotic yogurt had also a significant effect on the decrease of the WHC of chicken fillets during the storage time. Reduction of the cooking loss percentage is the consequences of postmortem denaturation of sarcoplasmic proteins such as glycogen phosphorylase [30]. The main cause of the increase in cooking loss percentage and the reduction of water holding capacity of treated samples could be due to the denaturation of proteins at $\mathrm{pH}$ close to the IP, resulting from the activity of proteolytic bacteria and the acidic $\mathrm{pH}$ created by the yogurt. Barbanti et al. (2005) and Murphy et al. (2000) concluded that the high temperature during the cooking 
TABLE 1: Average of chemical parameters of chicken fillet samples in different groups during storage period at $1 \pm 4^{\circ} \mathrm{C}(n=3)$.

\begin{tabular}{|c|c|c|c|c|c|}
\hline \multirow{2}{*}{ Parameter } & \multirow{2}{*}{ Group } & \multicolumn{4}{|c|}{ Days } \\
\hline & & 0 & 2 & 6 & 8 \\
\hline \multirow{3}{*}{$\mathrm{pH}$} & Control & $6.15 \pm 0.04^{\mathrm{aA}}$ & $6.86 \pm 0.02^{\mathrm{aB}}$ & $7.82 \pm 0.01^{\mathrm{aC}}$ & $7.92 \pm 0.03^{\mathrm{aD}}$ \\
\hline & RY & $6.15 \pm 0.04^{\mathrm{aA}}$ & $5.22 \pm 0.00$ ьв & $4.86 \pm 0.00 \mathrm{bC}$ & $4.71 \pm 0.00 \mathrm{bD}$ \\
\hline & PY & $6.15 \pm 0.04^{\mathrm{aA}}$ & $5.09 \pm 0.12^{\mathrm{bB}}$ & $5.01 \pm 0.01{ }^{\mathrm{cB}}$ & $4.74 \pm 0.00 \mathrm{bC}$ \\
\hline \multirow{3}{*}{ Cooking loss (\%) } & Control & $57 \pm 0.03^{\mathrm{aA}}$ & $60 \pm 0.02$ & $59 \pm 0.04^{\mathrm{aA}}$ & $61 \pm 0.04^{\mathrm{aA}}$ \\
\hline & RY & $57 \pm 0.03^{\mathrm{aA}}$ & $56 \pm 0.00^{\mathrm{abAB}}$ & $50 \pm 0.02 b^{B C}$ & $48 \pm 0.02^{\mathrm{bC}}$ \\
\hline & PY & $57 \pm 0.03^{\mathrm{aA}}$ & $54 \pm 0.00^{\mathrm{bA}}$ & $46 \pm 0.00 \mathrm{bB}$ & $44 \pm 0.00 \mathrm{bB}$ \\
\hline \multirow{3}{*}{ EXW (\%) } & Control & $28 \pm 0.02^{\mathrm{aA}}$ & $44 \pm 0.01^{\mathrm{aB}}$ & $37 \pm 0.04^{\mathrm{aAB}}$ & $34 \pm 0.04^{\mathrm{aA}}$ \\
\hline & RY & $28 \pm 0.02^{\mathrm{aA}}$ & $42 \pm 0.011^{\mathrm{aB}}$ & $61 \pm 0.00^{\mathrm{bC}}$ & $52 \pm 0.00^{\mathrm{aD}}$ \\
\hline & PY & $28 \pm 0.02 \mathrm{aA}$ & $38 \pm 0.02 \mathrm{aAB}$ & $47 \pm 0.07$ abBC & $53 \pm 0.00 \mathrm{aC}$ \\
\hline \multirow{3}{*}{ TBARS (mg MDAeq/kg) } & Control & $0.22 \pm 0.00^{\mathrm{aA}}$ & $0.23 \pm 0.00^{\mathrm{aAB}}$ & $0.24 \pm 0.00^{\mathrm{aAB}}$ & $0.26 \pm 0.02^{\mathrm{aB}}$ \\
\hline & RY & $0.22 \pm 0.00^{\mathrm{aA}}$ & $0.23 \pm 0.00^{\mathrm{abA}}$ & $0.23 \pm 0.00 \mathrm{abA}$ & $0.2 \pm 0.00^{\mathrm{bB}}$ \\
\hline & PY & $0.22 \pm 0.00^{\mathrm{aA}}$ & $0.22 \pm 0.00^{\mathrm{abA}}$ & $0.2 \pm 0.01^{\mathrm{bcAB}}$ & $0.18 \pm 0.00^{\mathrm{bB}}$ \\
\hline
\end{tabular}

${ }^{1}$ Significant difference $(P<0.05)$ between data is expressed by different letters. Lowercase letters show significant difference between various treatments in a column, while uppercase letters indicate significant difference in a row among the same treatments during the storage period (nonmarinated samples (Control), regular-yogurt-marinated samples (RY), and probiotic-yogurt-marinated samples (PY)); mean values \pm SD.

process causes denaturation of myofibrillar proteins, thereby shrinking the muscle fiber and increasing the cooking loss $[31,32]$. Various factors such as the presence of ionic calcium in yogurt and providing a close $\mathrm{pH}$ to the isoelectric point of meat protein (IP 5.5), as well as destroying the structure of proteins, set the stage for the WHC and the cooking loss decrease in samples treated with regular and probiotic yogurt $[33,34]$. At $\mathrm{pH}$ values below and above the isoelectric point, the net charge of most protein molecules becomes negative or positive, which results in the increase of the WHC.

3.3. TBARS Value. The fresh chicken meat is very susceptible to lipid oxidation due to high protein and moisture content, as well as high pH close to neutral. Hydroperoxides, as the initial products of lipid oxidation, are very unstable and convert to secondary products, such as malondialdehyde. Generally, secondary products of lipid oxidation do contribute to the improper sensory characteristics of meat products [35]. Therefore, TBARS value is measured to indicate lipid oxidation products, particularly aldehydes. As shown in Table 1 , on day 0 , the TBARS value of meat samples was $0.22 \mathrm{mg}$ MDA eq $/ \mathrm{kg}$, which was lower than the maximum tolerable limit of TBARS (4 mg MDA eq/kg). In comparison with untreated samples, chicken fillets marinated with RY and PY showed lower lipid oxidation products during the storage period, which was in agreement with previous studies [36-38]. As expected, the TBARS value of control samples increased during the storage period, but it remained relatively constant or even decreased in RY- and PY-treated samples. Zhang et al. (2011) studied the antioxidative activity of lactic acid bacteria in yogurt and described two relevant pathways including enzymatic and nonenzymatic defense systems to retard the oxidation. In the case of enzymatic defense, antioxidant enzymes, such as superoxide dismutase (SOD) and glutathione peroxidase $(\mathrm{GPx})$, eliminate toxic effects of superoxide anions and scavenge hydrogen peroxide and hydroxyl radicals. On the other hand, through the nonenzymatic pathway, the defense mechanism of cells and organisms develops, including reduction activity and the chelating capacity of metal ions, which can eliminate active oxygen $[39,40]$.

3.4. Texture Profile Parameters. A high correlation between sensory and instrumental texture profile analysis (TPA) has been reported for meat and meat products [41, 42].

Table 2 illustrates the TPA parameters of all samples on 0 , third, and sixth day of storage. A reduction was observed in the hardness value of all chicken fillet samples compared to the first day. At the end of the storage period, the greatest decrease in the hardness was observed in control samples. Although the hardness of RY-treated chicken fillets showed a slight decrease on the third day, it was not statistically significant, while the probiotic yogurt reduced the hardness of meat samples significantly in comparison with the control ones. On the other hand, the changes in cohesiveness and springiness of chicken breast meat were not statistically significant neither in the treated samples nor in the control ones, while the lowest and highest mean of the springiness were observed in the control and the PY-treated samples, respectively. Springiness is the extent to which a deformed sample returns to its original size and shape after compression [43].

On the $6^{\text {th }}$ day, the gumminess pattern of control and RY-treated samples showed a continuous decreasing trend. However, in the samples treated with probiotic yogurt, gumminess value increased slightly after 6 days in comparison with control samples. Regarding the chewiness, in the control group, the highest and lowest values were observed after 3 and 6 days, respectively. Changes in this parameter were not statistically significant in any of the sample groups.

The results showed a negative correlation between the cohesiveness and other tissue properties of chicken fillet samples stored in the fridge during the storage. Reduction of the hardness at the end of the storage period indicated the chicken breast meat softening during the storage in the fridge, and it can be concluded that the treatments did not have a 
TABLE 2: Average of parameters of texture profile analysis for chicken fillet samples in different groups during storage period at $1 \pm 4^{\circ} \mathrm{C}(n=3)$.

\begin{tabular}{|c|c|c|c|c|}
\hline \multirow{2}{*}{ Parameter } & \multirow{2}{*}{ Group } & \multicolumn{3}{|c|}{ Days } \\
\hline & & 0 & 3 & 6 \\
\hline \multirow{3}{*}{ Hardness (g) } & Control & $1303 \pm 110.30^{\mathrm{aA}}$ & $601 \pm 0.7^{\mathrm{aB}}$ & $248 \pm 36.06^{\mathrm{aC}}$ \\
\hline & RY & $1303 \pm 110.30^{\mathrm{aA}}$ & $1100.25 \pm 31.46^{\mathrm{bAB}}$ & $552.5 \pm 359.92^{\mathrm{abB}}$ \\
\hline & PY & $1303 \pm 110.30^{\mathrm{aA}}$ & $548.75 \pm 138.94^{\mathrm{aB}}$ & $1033 \pm 204.85^{\mathrm{bA}}$ \\
\hline \multirow{3}{*}{ Cohesiveness } & Control & $0.34 \pm 0.12^{\mathrm{aA}}$ & $0.53 \pm 0.25^{\mathrm{aA}}$ & $0.37 \pm 0.09^{\mathrm{aA}}$ \\
\hline & RY & $0.34 \pm 0.12^{\mathrm{aA}}$ & $0.31 \pm 0.02^{\mathrm{aA}}$ & $0.33 \pm 0.19^{\mathrm{aA}}$ \\
\hline & PY & $0.34 \pm 0.12^{\mathrm{aA}}$ & $0.41 \pm 0.13^{\mathrm{aA}}$ & $0.32 \pm 0.02^{\mathrm{aA}}$ \\
\hline \multirow{3}{*}{ Springiness (mm) } & Control & $8.04 \pm 1.32^{\mathrm{aA}}$ & $10.19 \pm 4^{\mathrm{aA}}$ & $4.88 \pm 1.56^{\mathrm{aA}}$ \\
\hline & RY & $8.04 \pm 1.32^{\mathrm{aA}}$ & $7.47 \pm 0.9^{\mathrm{aA}}$ & $6.02 \pm 2.36^{\mathrm{aA}}$ \\
\hline & PY & $8.04 \pm 1.32^{\mathrm{aA}}$ & $8.48 \pm 2.38^{\mathrm{aA}}$ & $7.89 \pm 1.28^{\mathrm{aA}}$ \\
\hline \multirow{3}{*}{ Gumminess (g) } & Control & $431.45 \pm 126.92^{\mathrm{aA}}$ & $317 \pm 153.44^{\mathrm{aA}}$ & $94.54 \pm 36.7^{\mathrm{aA}}$ \\
\hline & RY & $431.45 \pm 126.92^{\mathrm{aA}}$ & $350 \pm 11.31 \mathrm{aAB}$ & $156.6 \pm 81.13^{\mathrm{aB}}$ \\
\hline & PY & $431.45 \pm 126.92^{\mathrm{aA}}$ & $218.25 \pm 14.91^{\mathrm{aA}}$ & $337.8 \pm 82.38^{\mathrm{bA}}$ \\
\hline \multirow{3}{*}{ Chewiness (mJ) } & Control & $32.22 \pm 4.42^{\mathrm{aA}}$ & $34.71 \pm 27.81^{\mathrm{aA}}$ & $4.81 \pm 3.21^{\mathrm{aA}}$ \\
\hline & RY & $32.22 \pm 4.42^{\mathrm{aA}}$ & $25.63 \pm 2.27^{\mathrm{aAB}}$ & $10.40 \pm 9.34^{\mathrm{abB}}$ \\
\hline & PY & $32.22 \pm 4.42^{\mathrm{aA}}$ & $17.98 \pm 3.85^{\mathrm{aA}}$ & $26.23 \pm 7.64^{\mathrm{bA}}$ \\
\hline
\end{tabular}

${ }^{1}$ Significant difference $(P<0.05)$ between data is expressed by different letters. Lowercase letters show significant difference between various treatments in a column, while uppercase letters indicate significant difference in a row among the same treatments during the storage period (nonmarinated samples (control), regular-yogurt-marinated samples (RY), and probiotic-yogurt-marinated samples (PY)); mean values \pm SD.

TABLE 3: Microbial average changes of chicken fillet samples in different groups during storage period at $1 \pm 4^{\circ} \mathrm{C}(n=3)$.

\begin{tabular}{|c|c|c|c|c|c|c|}
\hline \multirow{2}{*}{ Parameter } & \multirow{2}{*}{ Group } & \multicolumn{5}{|c|}{ Days } \\
\hline & & 0 & 3 & 5 & 7 & 9 \\
\hline \multirow{3}{*}{ Staphylococcus aureus (log CFU/g) } & Control & $4.3 \pm 0.0^{\mathrm{aA}}$ & $5.4 \pm 0.2^{\mathrm{aB}}$ & $6.4 \pm 0.0^{\mathrm{aC}}$ & $6.7 \pm 0.0^{\mathrm{aD}}$ & $6.0 \pm 0.0^{\mathrm{aD}}$ \\
\hline & RY & $4.3 \pm 0.0^{\text {aA }}$ & $3.8 \pm 0.1 \mathrm{aB}$ & $3.6 \pm 0.0^{\mathrm{bA}}$ & $3.8 \pm 0.0^{\mathrm{bB}}$ & $4.0 \pm 0.0^{\mathrm{bC}}$ \\
\hline & PY & $4.3 \pm 0.0^{\mathrm{aA}}$ & $4.1 \pm 0.1 \mathrm{bC}$ & $3.0 \pm 0.0^{\mathrm{aA}}$ & $4.5 \pm 0.0 \mathrm{aD}$ & $3.3 \pm 0.1 \mathrm{aB}$ \\
\hline \multirow{3}{*}{ Fecal coliforms (log CFU/g) } & Control & $3.9 \pm 0.1 \mathrm{aA}$ & $5.8 \pm 0.0^{\mathrm{aB}}$ & $7.8 \pm 0.0^{\mathrm{aC}}$ & $8.9 \pm 0.0^{\mathrm{bD}}$ & $8.9 \pm 0.0^{\mathrm{aD}}$ \\
\hline & RY & $3.9 \pm 0.1^{\mathrm{aA}}$ & $4.9 \pm 0.0^{\mathrm{bB}}$ & $5.8 \pm 0.0^{\mathrm{bC}}$ & $6.2 \pm 0.0^{\mathrm{bD}}$ & $6.4 \pm 0.0^{\mathrm{bD}}$ \\
\hline & PY & $3.9 \pm 0.1 \mathrm{aA}$ & $4.2 \pm 0.0^{\mathrm{aB}}$ & $5.6 \pm 0.0^{\mathrm{aC}}$ & $6.1 \pm 0.0^{\mathrm{aD}}$ & $6.2 \pm 0.0^{\mathrm{aD}}$ \\
\hline \multirow{3}{*}{ Mold and yeast $(\log \mathrm{CFU} / \mathrm{g})$} & Control & $4.2 \pm 0.0^{\mathrm{aA}}$ & $6.2 \pm 0.1 \mathrm{cB}$ & $8.3 \pm 0.2^{b C}$ & $8.8 \pm 0.0^{\mathrm{cD}}$ & $8.8 \pm 0.0^{\mathrm{cD}}$ \\
\hline & RY & $4.2 \pm 0.0^{\mathrm{aA}}$ & $5.8 \pm 0.0^{\mathrm{bB}}$ & $5.6 \pm 0.1^{\mathrm{aB}}$ & $6.0 \pm 0.0^{\mathrm{aC}}$ & $6.3 \pm 0.0^{\mathrm{aD}}$ \\
\hline & PY & $4.2 \pm 0.0^{\mathrm{aA}}$ & $5.4 \pm 0.0^{\mathrm{aB}}$ & $6.0 \pm 0.0^{\mathrm{aC}}$ & $6.3 \pm 0.0^{\mathrm{bD}}$ & $6.7 \pm 0.0^{\mathrm{bE}}$ \\
\hline
\end{tabular}

${ }^{1}$ Significant difference $(P<0.05)$ between data is expressed by different letters. Lowercase letters show significant difference between various treatments in a column, while uppercase letters indicate significant difference in a row among the same treatments during the storage period (nonmarinated samples (control), regular-yogurt-marinated samples (RY), and probiotic-yogurt-marinated samples (PY)); mean values \pm SD.

significant effect on this property. The inhibitory effect of lactobacilli on proteolytic bacteria caused the treated samples to experience a greater relative hardness compared to control samples. The lipid oxidation and the denaturation of proteins lead to changes in muscle integrity, denaturation, and accumulation of myofibrilar proteins in the chicken breast muscle. In a study by Angelovicova et al. (2013), the effect of probiotics and thyme essential oil was investigated on the texture of cooked chicken breast meat. It was concluded that treating the chicken meat with probiotics moderately increased the hardness, springiness, and chewiness, while samples treated with a combination of probiotics and thyme oil showed the lowest score for these textural attributes [44].

3.5. Microbial Parameters. Fresh or minimally processed meat products are very susceptible to microbial contamination during the various steps of production to consumption. Therefore, enumeration of fecal coliforms, Staphylococcus aureus, and yeasts and molds of samples is necessary in most safety standards. Changes in microbial counts of chicken fillet samples as a function of storage time at $4^{\circ} \mathrm{C}$ are shown in Table 3 . Based on the results, a significant inhibitory effect of regular yogurt and probiotic yogurt on the microbial count can be seen during the storage time. While the initial count of Staphylococcus aureus was $4.34 \mathrm{log}$ $\mathrm{CFU} / \mathrm{g}$, it reached to $6.00,4.02$, and 3.38 in control, RYtreated, and PY-treated samples, respectively, after 9 days. The growth pattern of Staphylococcus aureus in chicken meat samples indicated that marinating chicken fillets with regular or probiotic yogurt could reduce the bacterial growth. The growth rate of fecal coliforms in samples treated with RY and PY was lower than the control group. The initial count of fecal coliform was $3.91 \log \mathrm{CFU} / \mathrm{g}$, which increased during 9 days of storage and reached the final population of 8.91, 6.4, and 6.24log CFU/g in control, RY-treated, and PY-treated samples, respectively. The initial yeast-mold population was $4.21 \log \mathrm{CFU} / \mathrm{g}$ and increased to $8.87 \mathrm{log} \mathrm{CFU} / \mathrm{g}$ in control samples, 6.34 log CFU/g in RY-treated samples, and $6.7 \mathrm{log}$ $\mathrm{CFU} / \mathrm{g}$ in PY-treated samples after 9 days of storage. 
The protective effect of lactic acid bacteria in fermented food is mainly due to acidic conditions in the food matrix that is provided through the fermentation of carbohydrates into organic acids (lactic acid and acetic acid) as well as the production of growth inhibitors, such as formic acid, free fatty acids, ethanol, hydrogen peroxide, diacetyl, acetoin, 2.3-butanediol, acetaldehyde, benzoate, bacteriolytic enzymes, bacteriocins, and antibiotics, with an antagonistic effect on a wide range of microorganisms. These agents have antagonistic effects through several ways, such as the elimination of the essential nutrients, the accumulation of D-amino acids, the reduction of the oxidation-reduction potential, and the adhesion of various bacteria. Arena et al. (2016) investigated the antibacterial effects of lactobacillus plantarum against pathogenic bacteria Escherichia coli O157 : H7, Staphylococcus aureus, Salmonella enteritidis, and Listeria monocytogenes. The results revealed that L. plantarum 105 had the strongest antagonistic activity against L. monocytogenes, while L. plantarum 106 and 107 had antimicrobial effects against Escherichia coli O157: H7 [45]. In another study, Idaomar et al. (2014) evaluated the application of a bacteriocin-like substance produced by Enterococcus durans E204 isolated from camel milk, to inhibit pathogenic bacteria (Listeria monocytogenes CECT 4032) in goat jben which is a Moroccan traditional fresh cheese. They added approximately $10^{6} \mathrm{CFU} / \mathrm{ml}$ Enterococcus durans E204 to six jben samples. The results revealed a significant decrease in the population of L. monocytogenes after 8 and 6 days with $10^{6}$ and $10^{4} \mathrm{CFU} / \mathrm{ml}$ Enterococcus durans E204 contamination [46].

\section{Conclusions}

Based on the results, it can be concluded that regular and probiotic yogurt can significantly reduce the number of Staphylococcus aureus in chicken breast meat and have antibacterial effects on Staphylococcus aureus due to the antimicrobial properties of lactobacilli. However, samples of chicken fillets treated with regular and probiotic yogurt could hardly inhibit the growth of mold and yeast as well as fecal coliforms. Additionally, for various reasons, such as the effect of yogurt dipping on samples, $\mathrm{pH}$ reduction, and acidification of samples, chemical degradation was significantly lower in samples treated with regular and probiotic yogurt. Therefore, the lipid oxidation decreases and the proteolytic bacteria inactivation in the acidic environment enhances the physical properties associated with the chicken breast meat tissue. According to the results, regular and probiotic yogurt can be used as a food dipping, which would improve the microbial and physicochemical properties of chicken fillets.

In comparison between RY- and PY-treated chicken fillets, there was no significant difference in microbial and physicochemical properties of marinated fillets. According to the higher price and more time demanding of probiotic yogurt production, marinating chicken fillets does not show economic efficiency unless the taste of the product improves, which is for more investigation on sensory evaluation of the products.

\section{Data Availability}

The data supporting the findings of this study are included within the article.

\section{Conflicts of Interest}

The authors declare that there are no conflicts of interest regarding the publication of this article.

\section{Acknowledgments}

This work was supported by the Shiraz University of Medical Sciences (Grant no. 95-01-84-11717).

\section{References}

[1] C. C. Balamatsia, E. K. Paleologos, M. G. Kontominas, and I. N. Savvaidis, "Correlation between microbial flora, sensory changes and biogenic amines formation in fresh chicken meat stored aerobically or under modified atmosphere packaging at $4^{\circ} \mathrm{C}$ : possible role of biogenic amines as spoilage indicators," Antonie Van Leeuwenhoek, vol. 89, no. 1, pp. 9-17, 2006.

[2] S. Vaithiyanathan, B. M. Naveena, M. Muthukumar, P. S. Girish, and N. Kondaiah, "Effect of dipping in pomegranate (Punica granatum) fruit juice phenolic solution on the shelf life of chicken meat under refrigerated storage $\left(4^{\circ} \mathrm{C}\right)$," Meat Science, vol. 88, no. 3, pp. 409-414, 2011.

[3] H. W. Gausman, J. H. Ramser, G. H. Dungan et al., "Some effects of artificial drying of corn grain," Plant Physiology, vol. 27, no. 4, pp. 794-802, 1952.

[4] B. S. M. Mahmoud, K. Yamazaki, K. Miyashita, Y. Kawai, I.-S. Shin, and T. Suzuki, "Preservative effect of combined treatment with electrolyzed $\mathrm{NaCl}$ solutions and essential oil compounds on carp fillets during convectional air-drying," International Journal of Food Microbiology, vol. 106, no. 3, pp. 331-337, 2006.

[5] R. K. Buick and A. P. Damoglou, "The effect of vacuum packaging on the microbial spoilage and shelf-life of 'readyto-use' sliced carrots," Journal of the Science of Food and Agriculture, vol. 38, no. 2, pp. 167-175, 1987.

[6] S. Yingyuad, S. Ruamsin, D. Reekprkhon, S. Douglas, S. Pongamphai, and U. Siripatrawan, "Effect of chitosan coating and vacuum packaging on the quality of refrigerated grilled pork," Packaging Technology and Science, vol. 19, no. 3 , pp. 149-157, 2006.

[7] J. D. Monk, L. R. Beuchat, and M. P. Doyle, "Irradiation inactivation of food-borne microorganisms," Journal of Food Protection, vol. 58, no. 2, pp. 197-208, 1995.

[8] D. G. Yordanov and G. V. Angelova, "High pressure processing for foods preserving," Biotechnology \& Biotechnological Equipment, vol. 24, no. 3, pp. 1940-1945, 2010.

[9] P. M. Davidson, T. M. Taylor, and S. E. Schmidt, "Chemical preservatives and natural antimicrobial compounds," in Food MicrobiologyAmerican Society for Microbiology (ASM), Washington, NJ, USA, 2013.

[10] A. Soomro, T. Masud, and K. Anwaar, "Role of lactic acid bacteria (LAB) in food preservation and human health-a review," Pakistan Journal of Nutrition, vol. 1, no. 1, pp. 20-24, 2002.

[11] S. M. Abdollahzadeh, M. R. Zahedani, S. Rahmdel, F. Hemmati, and S. M. Mazloomi, "Development of Lactobacillus acidophilus-fermented milk fortified with date 
extract," Lebensmittel-Wissenschaft \& Technologie, vol. 98, pp. 577-582, 2018.

[12] A. Kazemi, Effect of Adding Soymilk on Physicochemical, Microbial, and Sensory Characteristics of Probiotic Fermented Milk Containing Lactobacillus Acidophilus, 2014.

[13] F. Gaggia, D. Di Gioia, L. Baffoni, and B. Biavati, "The role of protective and probiotic cultures in food and feed and their impact in food safety," Trends in Food Science \& Technology, vol. 22, pp. S58-S66, 2011.

[14] P. Shokryazdan, M. Faseleh Jahromi, J. B. Liang, and Y. W. Ho, "Probiotics: from isolation to application," Journal of the American College of Nutrition, vol. 36, no. 8, pp. 666676, 2017.

[15] A. Gálvez, H. Abriouel, N. Benomar, and R. Lucas, "Microbial antagonists to food-borne pathogens and biocontrol," Current Opinion in Biotechnology, vol. 21, no. 2, pp. 142-148, 2010.

[16] L. Settanni and A. Corsetti, "Application of bacteriocins in vegetable food biopreservation," International Journal of Food Microbiology, vol. 121, no. 2, pp. 123-138, 2008.

[17] P. A. Vandenbergh, "Lactic acid bacteria, their metabolic products and interference with microbial growth," FEMS Microbiology Reviews, vol. 12, no. 1-3, pp. 221-237, 1993.

[18] Z. Hassanzadeh-Rostami, "Mixtures of soy-and cow's milk as potential probiotic food carriers," J. Biology and Today's World, vol. 4, no. 1, pp. 29-33, 2015.

[19] P. A. Maragkoudakis, K. C. Mountzouris, D. Psyrras et al., "Functional properties of novel protective lactic acid bacteria and application in raw chicken meat against Listeria monocytogenes and Salmonella enteritidis," International Journal of Food Microbiology, vol. 130, no. 3, pp. 219-226, 2009.

[20] U. Göğüş, F. Bozoglu, and S. Yurdugul, "The effects of nisin, oil-wax coating and yogurt on the quality of refrigerated chicken meat," Food Control, vol. 15, no. 7, pp. 537-542, 2004.

[21] H. Vergara and L. Gallego, "Effects of gas composition in modified atmosphere packaging on the meat quality of Spanish Manchega lamb," Journal of the Science of Food and Agriculture, vol. 81, no. 14, pp. 1353-1357, 2001.

[22] Y. Shen, X. Guo, X. Li et al., "Effect of cooking temperatures on meat quality, protein carbonylation and protein crosslinking of beef packed in high oxygen atmosphere," Lebensmittel-Wissenschaft \& Technologie, vol. 154, p. 112633, 2022.

[23] E. Pelicano, P. D. Souza, H. D. Souza et al., "Effect of different probiotics on broiler carcass and meat quality," Revista Brasileira de Ciência Avícola, vol. 5, no. 3, pp. 207-214, 2003.

[24] J. Pokorny and A. Dieffenbacher, "Determination of 2-thiobarbituric acid value: direct method - results of a collaborative study and the standardised method," Pure and Applied Chemistry, vol. 61, no. 6, pp. 1165-1170, 1989.

[25] A. Soyer, B. Özalp, Ü. Dalmış, and V. Bilgin, "Effects of freezing temperature and duration of frozen storage on lipid and protein oxidation in chicken meat," Food Chemistry, vol. 120, no. 4, pp. 1025-1030, 2010.

[26] F. R. De Huidobro, E. Miguel, B. Blázquez, and E. Onega, "A comparison between two methods (Warner-Bratzler and texture profile analysis) for testing either raw meat or cooked meat," Meat Science, vol. 69, no. 3, pp. 527-536, 2005.

[27] F. Ghollasi-Mood, "Microbial and chemical spoilage of chicken meat during storage at isothermal and fluctuation temperature under aerobic conditions," Iranian Journal of Veterinary Science and Technology, vol. 8, no. 1, pp. 38-46, 2017.

[28] A. Grajales-Lagunes, C. Rivera-Bautista, M. Ruiz-Cabrera, R. Gonzalez-Garcia, J. Ramirez-Telles, and M. Abud-Archila,
"Effect of lactic acid on the meat quality properties and the taste of pork Serratus ventralis muscle," Agricultural and Food Science, vol. 21, no. 2, pp. 171-181, 2012.

[29] M. J. Fraqueza, M. C. Ferreira, and A. S. Barreto, "Spoilage of light (PSE-like) and dark Turkey meat under aerobic or modified atmosphere package: microbial indicators and their relationship with total volatile basic nitrogen," British Poultry Science, vol. 49, no. 1, pp. 12-20, 2008.

[30] B. Bowker and H. Zhuang, "Relationship between waterholding capacity and protein denaturation in broiler breast meat," Poultry Science, vol. 94, no. 7, pp. 1657-1664, 2015.

[31] D. Barbanti and M. Pasquini, "Influence of cooking conditions on cooking loss and tenderness of raw and marinated chicken breast meat," Lebensmittel-Wissenschaft und -Technologie- Food Science and Technology, vol. 38, no. 8, pp. 895-901, 2005.

[32] R. Y. Murphy and B. P. Marks, "Effect of meat temperature on proteins, texture, and cook loss for ground chicken breast patties," Poultry Science, vol. 79, no. 1, pp. 99-104, 2000.

[33] S. Barbut, "Colour measurements for evaluating the pale soft exudative (PSE) occurrence in Turkey meat," Food Research International, vol. 26, no. 1, pp. 39-43, 1993.

[34] J. K. Northcutt, E. A. Foegeding, and F. W. Edens, "Waterholding properties of thermally preconditioned chicken breast and leg meat," Poultry Science, vol. 73, no. 2, pp. 308-316, 1994.

[35] M. Kostaki, V. Giatrakou, I. N. Savvaidis, and M. G. Kontominas, "Combined effect of MAP and thyme essential oil on the microbiological, chemical and sensory attributes of organically aquacultured sea bass (Dicentrarchus labrax) fillets," Food Microbiology, vol. 26, no. 5, pp. 475-482, 2009.

[36] M. B. Let, C. Jacobsen, and A. S. Meyer, "Lipid oxidation in milk, yoghurt, and salad dressing enriched with neat fish oil or pre-emulsified fish oil," Journal of Agricultural and Food Chemistry, vol. 55, no. 19, pp. 7802-7809, 2007.

[37] M. Y. Lin and C. L. Yen, "Reactive oxygen species and lipid peroxidation product-scavenging ability of yogurt organisms," Journal of Dairy Science, vol. 82, no. 8, pp. 1629-1634, 1999.

[38] M. Serra, A. J. Trujillo, J. Pereda, B. Guamis, and V. Ferragut, "Quantification of lipolysis and lipid oxidation during cold storage of yogurts produced from milk treated by ultra-high pressure homogenization," Journal of Food Engineering, vol. 89, no. 1, pp. 99-104, 2008.

[39] S. Zhang, "Antioxidative activity of lactic acid bacteria in yogurt," African Journal of Microbiology Research, vol. 5, no. 29, pp. 5194-5201, 2011.

[40] Y. Wang, Y. Wu, Y. Wang et al., "Antioxidant properties of probiotic bacteria," Nutrients, vol. 9, no. 5, p. 521, 2017.

[41] J.-F. C. Meullenet, J. A. Carpenter, B. G. Lyon, and C. E. Lyon, "Bi-cyclical instrument for assessing texture profile parameters and its relationship to sensory evaluation of texture," Journal of Texture Studies, vol. 28, no. 1, pp. 101-118, 1997.

[42] J.-F. Meullenet, B. G. Lyon, J. A. Carpenter, and C. E. Lyon, "Relationship between sensory and instrumental texture profile attributes," Journal of Sensory Studies, vol. 13, no. 1, pp. 77-93, 1998.

[43] N. P. Bramesco and C. S. Setser, "Application of sensory texture profiling to baked products: some considerations for evaluation, definition of parameters and reference products," Journal of Texture Studies, vol. 21, no. 3, pp. 235-252, 1990.

[44] M. Angelovicova, "Effect of probiotics and thyme essential oil on the texture of cooked chicken breast meat," Acta 
Scientiarum Polonorum Technologia Alimentaria, vol. 12, no. 4, pp. 379-384, 2013.

[45] M. P. Arena, A. Silvain, G. Normanno et al., "Use of Lactobacillus plantarum strains as a bio-control strategy against food-borne pathogenic microorganisms," Frontiers in $\mathrm{Mi}$ crobiology, vol. 7, p. 464, 2016.

[46] M. Idaomar, N. El Moussaoui, and J. Abrini, “Application of a bacteriocin-like inhibitory substance producing Enterococcus durans E204 strain, isolated from camel milk, to control Listeria monocytogenes CECT 4032 in goat jben," Annals of Microbiology, vol. 64, no. 1, pp. 313-319, 2014. 